\title{
Safflower Oil
}

National Cancer Institute

\section{Source}

National Cancer Institute. Safflower Oil. NCI Thesaurus. Code C820.

An oil derived from the seed of the safflower, and chemically similar to sunflower oil. Two principal varieties differ in the type of fatty acids predominating the oil: those which are high in oleic acid, and those which are high in linoleic acid. The main uses of safflower oil are in cooking oils and in production of margarine and salad dressing. 